\title{
Solar driven produced water treatment for beneficial uses
}

\author{
Ralph Gunness ${ }^{A, D}$, Hensley Wee ${ }^{B}$, Ronald Lee ${ }^{B}$, Luong N. Nguyen ${ }^{C}$ and Long D. Nghiem ${ }^{C}$ \\ ${ }^{\text {A }}$ Bridgeport Energy Limited, Level 7, 111 Pacific Highway, North Sydney NSW 2060 \\ B JWA Oilfied Supplies Pty Ltd, 35 Griffin Crescent, Brendale QLD 4500 \\ ${ }^{\mathrm{C}}$ Center for Technology in Water and Wastewater, University of Technology Sydney, PO Box 123, \\ Broadway NSW 2007 \\ D Corresponding author. Email: RGunness@ bridgeport.net.au
}

\begin{abstract}
This study evaluates the feasibility of an emerging technology - Concentrated Solar MultiEffect Distiller (CSMED) - to supply high quality water for beneficial use at Eromanga, which is located in a remote and dry region of Australia. Produced water from the Kenmore oil field is the only reliable water source at Eromanga and has been approved for livestock watering. The process utilises concentrated solar technology to drive a multi-effect distiller, making the process ideal for the Australian Outback. Historical water parameters of the produced water were assessed against the water guideline for irrigation, livestock watering, municipal, and potable use. The proposed treatment will further improve key water quality parameters to exceed guideline requirements for unrestricted water uses mentioned above. The CSMED produces a high-quality distillate (i.e. treated water) free of all mineral salts and can be mixed with the produced water to increase the final product water volume. An Excel based model was developed to determine suitable blending ratio while maintain the water quality for each beneficial use. For production of livestock watering and potable use, a blending ratio (of at least $19 \% \mathrm{v} / \mathrm{v}$ ) between the CSMED distillate and produced water can be applied, significantly increasing the final water volume. The Excel based model could also indicate chemical addition for adjustment of SAR in case of irrigation application. The brine from CSMED can potentially be used to prepare drilling for oil field operation. An on-site performance study of the CSMED system has been planned to validate these results.
\end{abstract}

Keywords: Concentrated solar multi-effect distiller; Oil operations; Produced water; Water quality guideline; Beneficial water uses. 


\section{Introduction}

At the Kenmore oil field, about 1,200 ML/yr is produced from the precipice formation reservoir from a depth of about $2 \mathrm{~km}$ during oil operations. This produced water is brackish to slightly saline and dominated by sodium, bicarbonate, chloride, and fluoride. Without treatment, direct irrigation of the high sodium produced water can lead to soil degradation. In addition, the water quality and volume of produced water varies greatly from basin to basin and with the wells age. Treatment of the produced water to a standard, which is compatible or exceeds the water quality guideline, is beneficial to the environment, water users, and water-dependent industries (Millar et al., 2016; Nghiem et al., 2011). The treated water would be a valuable resource for industrial users in inland Australia where water supply is difficult or uncertain. Livestock watering, irrigation, municipal use, dust suppression, and drinking water are the potential application of treated water (Blair et al., 2017).

Conventional approach for produced water treatment includes microfiltration, ultrafiltration, or ion exchange softening as pre-treatment prior to reverse osmosis (Blair et al., 2017). This conventional approach is too complex for produced water treatment at a remote location, which is typical to most oil and gas production facilities. The variation in the produced water volume and its chemical composition over the life of the wells also induces a significant challenge on the operation of membrane-based process.

The thermally driven distillation method has a number of advantages over the membrane-based process. The process relies on evaporation to separate salts from water. Thus, it has a $100 \%$ theoretical rejection of non-volatile solutes. This characteristic is suitable for treatment of produced water, which is rich in dissolved salts. Consistent and high purity of treated water can be achieved regardless of the produced water quality. The thermal process can handle relatively dirty produced water at high water recovery, alleviating the need of pre-treatment and reducing waste brine volume (Nghiem et al., 2011; Tao et al., 2018). The challenges of the thermal process are its large footprint and energy intensive (Tao et al., 2018). These challenges are expected to be less when the thermal process is applied at oil production field, which has abundant space and solar energy.

This study aims to evaluate the feasibility of a thermal driven - concentrated solar multi-effect distillation technology for the treatment of high-ionic content produced water in a very remote community but with excellent solar thermal resource. An Excel based model is developed to estimate the blending ratio between the treated water and the produced water to generate water for livestock watering, irrigation, municipal use, and potable use. Potential application of the high ionic waste brine in the drilling mud is also discussed. This system is envisioned as a complete solution for the produced water at oil production field. 


\section{Materials and Methods}

Produced water from the Kenmore oil field

The Kenmore oil field is located in the Eromanga Basin of far southwest Queensland (Skinner et al., 2006). Bridgeport has begun oil production at the site since March 2017. The Kenmore oil reservoir is formed between the Hutton Sandstone and Birkhead Formation, which acts as reservoir and seal, respectively (Watts, 1987). Oil production at Kenmore is accompanied by the co-production of 1,200 ML/yr produced water. This water is from the same geological formation at 1.4 to $1.8 \mathrm{~km}$ deep and capped by the Birkhead formation, thus, preventing any impact on shallow aquifers (less than $150 \mathrm{~m}$ in depth). Key water quality parameters are routinely assessed using approved analytical methods to ensure compliance with the Kenmore Oil Field EPA license thresholds.

\section{Water supply and solar thermal at Eromanga}

The Kenmore oil filed is located in Eromanga, one of the driest regions in Australia. The average annual rainfall at Eromanga is less than $350 \mathrm{~mm} / \mathrm{yr}$. Most of this rainfall occurs as infrequent storms thus cannot be readily captured and stored for beneficial use. On the other hand, Eromanga has excellence solar resource. The annual solar irradiation at Eromanga is more than 2,000 kWh/m² (https://solargis.com/maps-and-gis-data/download/australia). As a result, at Eromanga, annual evaporation is four time higher than rainfall. Thus, produced water from Kenmore presents an excellent opportunity for local beneficial uses. Significant water demand in the region comes from livestock watering, irrigation of land for sheep and cattle grazing, replacing drinking water for municipal usages (equipment cleaning or dust suppression), and potable water supply.

\section{Overall water purification scheme}

The concentrated solar multi-effect distiller (CSMED) unit is the core of the treatment scheme (Figure 1). Distillate from the CSMED is expected to be free of all dissolved salts. Thus, to eliminate the need for remineralisation and to increase the treatment capacity, a bypass line with possible chemical amendment is proposed. Chemical amendment includes the addition of a small quantity of calcium or magnesium salts to adjust the sodium adsorption ratio (SAR) and $\mathrm{pH}$. The treatment scheme aims for robust and reliable operation in remote location.

The water quality for livestocking, irrigation, and municipal use must meet the Australian and New Zealand Guidelines for Fresh and Marine Water Quality (ANZECC, 2000). Drinking water produced by this treatment scheme must meet the Australian Drinking Water Guideline (NHMRC \& NRMMC, 2019). The water quality values in these guidelines are used to design the overall treatment scheme.

An Excel based model was developed to determine the bypass volume using mass balance calculation. Equations used to develop the Excel based model are available in the Appendix. The demand of either calcium or magnesium for chemical amendment is also calculated based on a mass 
balance to achieve the specified SAR target. The model allows the end-user to select the target beneficial use and simulate range scenarios including changes in produced water quality, target water parameters, water recovery, and salt removal by the CSMED unit, and treatment capacity.

\section{Concentrated solar multi-effect distiller}

The pilot scale CSMED (Fig. 2) consists of five parabolic panels with the total area of $236 \mathrm{~m}^{2}$ and a multi-effect distiller. The solar collector is programmed to track the sun throughout the day. The multi-effect distiller is positioned along the longitudinal focal line to receive concentrated solar radiation.

Feed water (e.g. produced water) is transferred along the multi-effect distiller under vacuum at approximately $20 \mathrm{~mm} \mathrm{Hg}$. The parabolic trough concentrates sunlight to heat up water in the multieffect distiller, and thus induces the distillation process. The produced water vapour is drawn in the opposite direction with the feed water (Fig $2 b$ ) using vacuum pump for multi distillation effects and recovery of the latent heat when water vapour condenses to form distillate. The vacuum also reduces water boiling point to $60-65^{\circ} \mathrm{C}$ to accelerate the distillation process. The system is capable of producing $30-40 \mathrm{~m}^{3}$ of purified water per day.

The pilot CSMED was evaluated in batch mode at the manufacturer site. Performance data from this off-site pilot evaluation was used to develop the Excel based model. The pilot CSMED runs on solar energy and its water recovery is not limited by the osmotic pressure like in the membrane filtration process. Thus, zero liquid discharge or high solid content of the waste brine can be achieved.

There is a potential application of the waste brine onsite (e.g. drilling mud additive). Water-based drilling mud is an integral component in drilling of oil wells. It contains water as base fluid, polymer, and many other additives including reactive/inert solids and chemical to perform several key roles for safe and efficiency drilling (Yao et al., 2014). The waste brine from the CSMED is rich in ions, which could be used as "additives" for drilling muds.

In the Excel based model, the concentration of ions was calculated at a given water recovery for each of the beneficial uses. The ultimate aim is to swap out the commercial potassium chloride with the waste brine resulting from the CSMED process.

\section{Results and Discussion}

Feed water quality at the Kenmore oil field

The produced water quality from 2017 to 2019 and corresponding water parameters specified in the guideline for each of the intended beneficial use is summarised in Table 1. Several water quality parameters of produced water must be adjusted for each unique beneficial use. These parameters are highlighted in bold in Table 1. Key parameters of concern are salinity, fluoride, and SAR. 
Composition of the produced water from the Kenmore oil field is consistent with bore water throughout the region. Water conductivity and bicarbonate alkalinity values were in the range from 1,180 to $12,200 \mu \mathrm{S} / \mathrm{cm}$ and 574 to $590 \mathrm{mg} / \mathrm{L}$, respectively. There is some variation over time, mainly due to the different stages of oil extraction activities, as well as variation between specific oil wells. The observed variation is insignificant for this scoping study.

Similar to most bore-water in the region, fluoride concentration in produced water is in the range of 3.3 to $8.9(\mathrm{mg} / \mathrm{L})$, which is significantly higher than the guideline value for all beneficial uses. Fluoride is both an essential element and a water contaminant. A small amount of fluoride is essential to maintain healthy bone and teeth in humans and animals. On the other hand, excessive ingestion of fluoride can lead to a medical condition known as dental and skeletal fluorosis. As a result, fluoride concentration in water for drinking and livestocking is regulated (ANZECC, 2000; NHMRC \& NRMMC, 2019). The guideline value for fluoride in drinking water is $1.5 \mathrm{mg} / \mathrm{L}$ (NHMRC \& NRMMC, 2019). When water-containing fluoride is used for irrigation of pastureland and edible crop, fluoride can be transferred along the food chain. Thus, fluoride concentration in irrigation water is also regulated (ANZECC, 2000). It is recommended that the concentration of fluoride in irrigation waters should be less than $1 \mathrm{mg} / \mathrm{L}$ for long-term use (100 years) and $2 \mathrm{mg} / \mathrm{L}$ for short-term use (25 years) (ANZECC, 2000).

The value of SAR relates the amount of sodium to calcium and magnesium in water. The SAR of water can be calculated by using the following equation where all concentrations are expressed in meq/L (ANZECC, 2000).

$$
S A R=\frac{N a^{+}}{\sqrt{\frac{C a^{2+}+M g^{2+}}{2}}}
$$

The SAR value is an important water parameter for irrigation. Irrigation with high SAR water cause soil sodicity and soil structure (e.g. reduce infiltration, percolation and drainage) (ANZECC, 2000). Plants have difficulty extending their roots through sodic soils and may suffer from waterlogging and anoxia. Thus, there is list of SAR tolerance of plants (e.g. extremely sensitive SAR $=2-8$ for avocado, nut, and citrus) (ANZECC, 2000). The value of SAR in produced water at Kenmore Oil field was from 12.6 to 120. In the Excel based model, an SAR value of 8 (i.e. sensitive crops) was selected to determine the bypass volume.

The produced water from the wellhead also has an absence of water pathogens (E. Coli and $E$. Salmonella), which is relative for potable use in remote areas.

\section{CSMED water treatment performance}

The CSMED system was validated at the manufacturer's site before deployment to the Eromanga oil field. The validation test conditions aimed to demonstrate the capacity of producing 
high quality water and high solid content residue (Table 2). In test 1, the system produced $930 \mathrm{~L}$ distillate within 26 minutes. The water recovery and TDS removal was 78\% and 99.9\%, respectively. These values are consistent with the reported data from the thermal distillation process. In test 2, sand was mixed with water by a ratio of $50 \%$ by weight of water to create a high solid-content slurry. The system was able to produce distillate at $42 \mathrm{mg} / \mathrm{L}$ TDS and a low moisture content of $12 \mathrm{mg}$ of water per $100 \mathrm{~g}$ of residual sand. This is a notable outcome compare to the current membrane-based process, which results in high volume of waste brine in the treatment of produced water.

\section{Livestock watering}

Bridgeport has a current license to supply water with up to $8 \mathrm{mg} / \mathrm{L}$ of fluoride to a cattle farm for live stocking on the condition that animal health is continuously monitored. The animal healthmonitoring regime can be diminished when the fluoride concentration in livestock water is within the guideline. The recommended water quality guideline for unrestricted livestock consumption sets the fluoride value at $1 \mathrm{mg} / \mathrm{L}$ (ANZECC, 2000). Similarly, electrical conductivity and bicarbonate alkalinity concentration in the produced water is higher than the guideline value. Therefore, fluoride, conductivity, and bicarbonate concentration are considered in the Excel model.

As noted in Figure 1, a bypass line is designed to mix distillate from the CSMED with chemically amended co-produced to meet the target water quality guideline and increase treatment capacity. For each water parameter exceeding the guideline value, the Excel model is used to determine the bypass ratio. Water parameter with the smallest bypass ratio is used so that the final water meets all requirements in the guideline. For example, the guideline value of fluoride is $1 \mathrm{mg} / \mathrm{L}$ for livestock watering, resulting in a bypass ratio of $19 \%(\mathrm{v} / \mathrm{v})$ (Table 3). The bypass ratios based on electrical conductivity and bicarbonate alkalinity are 53 and 610\%, respectively. Thus, the overall bypass ratio of $19 \%$ is adapted if the fluoride limit for livestock watering is $1 \mathrm{mg} / \mathrm{L}$. Given the targeted product water volume of $40 \mathrm{~m}^{3}$ applying the bypass ratio, the CSMED will only need to produce $33.65 \mathrm{~m}^{3}$ and blend with $6.35 \mathrm{~m}^{3}$ to produce final product water for live stocking.

It is noted that $\mathrm{pH}$ value of the product water could not be calculated in the Excel based model. Distillate from the CSMED is expected to be acidic due to the high removal of water-soluble salts. It is recommended to measure the $\mathrm{pH}$ of the product water during the full-scale trial. The bypass ratio is expected to increase the $\mathrm{pH}$ value of the product water to within the guideline value $(5.5-8.5)$.

\section{Irrigation}

The water guideline of fluoride for irrigation recommends is at $1 \mathrm{mg} / \mathrm{L}$ for long-term trigger value (100 years) and $2 \mathrm{mg} / \mathrm{L}$ for short-term trigger value (25 years) (ANZECC, 2000). Using the same approach, our Excel based model predicts the bypass ratio of $19 \%$ (i.e. $6.35 \mathrm{~m}^{3}$ and $33.65 \mathrm{~m}^{3}$ treated water to make $40 \mathrm{~m}^{3}$ product water) (Table 4) for irrigation. 
A notable water parameter for irrigation use is the SAR. The SAR value is 8.04 under the bypass ratio of $19 \%$. This SAR value is amongst our targeted SAR window of 8-18 for pasture conditions. In the full-scale trial, Bridgeport will use the product water to rehabilitate an old evaporation pond. The process includes the percolation of existing salts through the soil and then the establishment of vegetation on surface of the rehabilitated area. The vegetation type is mainly buffel grass interspersed with saltbush at highest salinity areas and local acacia species, gigi, popular box eucalypt and senna cassia species. It is envisaged that treated water will be added to the old ponds by a recently purchased traveling irrigation system. Historic data indicates the SAR of local and pond soil in the range of $2.02-10$ and $46-138$, respectively. The low SAR value (8.04) in the irrigation water from the CSMED system is expected to lower the SAR value in the upper soil margin being suitable for the targeted vegetation.

It is also expected that sodium, calcium, and magnesium ion concentration in the produced water will change the SAR value. The Excel based model is designed to calculate the amount of calcium or magnesium addition to achieve specific SAR. For example, a $5.61 \mathrm{~kg}$ of calcium salt per $\mathrm{m}^{3}$ of the product water is required to decrease the SAR from 8.04 to 6 . Future trial on irrigation of crops and pastures in the community will be undertaken upon validation of this trial.

\section{Municipal use}

The municipal use is specific to the Kenmore oil field. The treated water can be mixed with produced water for local municipal use such as equipment washing, dust control and sewage treatment. If the water is used for municipal irrigation, the water quality is expected to be similar for irrigation as discussed above.

\section{Potable water use}

The product water could be used to supply potable water at the Township of Eromanga and the Bridgeport camp facilities. Fluoride and electrical conductivity are two notable water parameters since their concentration in the produced water are significantly higher than value in the Australian Drinking Water Guidelines (NHMRC \& NRMMC, 2019). The Excel model calculates the bypass ratio based on these two parameters. A bypass ratio of $31 \%(\mathrm{v} / \mathrm{v})$ was obtained to produce the product water at fluoride concentration of $1.5 \mathrm{mg} / \mathrm{L}$ (Table 5). However, the electrical conductivity in the product water is $652 \mu \mathrm{S} / \mathrm{cm}$, which is higher than the guideline value of $400 \mu \mathrm{S} / \mathrm{cm}$. A bypass ratio of $17 \%$ (v/v) was achieved based on the electrical conductivity value (Table 5). Accordingly, fluoride concentration was $0.93 \mathrm{mg} / \mathrm{L}$. Given the targeted product water volume of $40 \mathrm{~m}^{3}$ and applying the bypass ratio, the CSMED will only need to produce $34.2 \mathrm{~m}^{3}$ and blend with $5.8 \mathrm{~m}^{3}$ to produce potable water.

Using the waste brine as a drilling mud additive 
Potassium chloride is currently used as drilling mud additive at Kenmore oil field. The potassium ions $\left(\mathrm{K}^{+}\right)$attach to clay surfaces and lend stability to shale exposed to drilling fluids by the bit . The CSMED treatment produces a high ionic waste brine, which could be used to replace the potassium chloride in drilling mud.

The concentration of water parameters in the waste brine depends on the initial ionic concentration, water recovery, and removal efficiency by the CSMED (Nghiem et al., 2011). The water recovery of the CSMED is not limited by osmotic pressure, thus high ionic recoveries are in principle, are achievable depending on running time and heat energy. In the Excel based model, we adapt a recovery value of $78 \%$ (i.e. validation test 1 ). The CSMED produces $9.5 \mathrm{~m}^{3}$ of waste brine after treatment of $43 \mathrm{~m}^{3}$ produced water. The concentration of sodium, calcium, magnesium, and bicarbonate in the waste brine are 1572, 88.6, 68, and $2645 \mathrm{mg} / \mathrm{L}$, respectively. If the CSMED system were operated at $97 \%$ water recovery, the concentration of these ions will significantly increase to $11533\left(\mathrm{Na}^{+}\right), 650\left(\mathrm{Ca}^{2+}\right), 500\left(\mathrm{Mg}^{2+}\right)$ and 3966 (bicarbonate) $\mathrm{mg} / \mathrm{L}$. The ions in the waste brine are expected to simulate the ionic effect of $\mathrm{KCl}$ in commercial drilling mud. An experimental plan to study the rheological, thermal and filtration properties of drilling mud after addition of the waste brine is suggested. The success of this trial could have both economic and environmental benefits for Bridgeport.

\section{Conclusion and recommendations}

This study provided an overall design of a solar driven treatment process to beneficially reuse produced water from the Kenmore oil field for livestock watering, irrigation, municipal use, and potable water. Using extensive water quality monitoring over the last 3 years, an Excel based model for simulation, and short term pilot performance of a concentrated solar multi-effect distillation system, suitable treatment scenarios were analysed and discussed to ensure compliance with relevant water guideline regarding four water parameters namely fluoride, electrical conductivity, bicarbonate alkalinity, and SAR. The results indicate that all four desirable beneficial use options are achievable even with very conservative water quality targets. Since, distillate from the CSMED is of very high quality, a bypass volume of produced water can be mixed with the distillate prior to final use to reduce the cost of treatment. The bypass volume is sensitive toward the target value of fluoride and SAR. This study also considers using the brine from the CSMED to replace potassium addition to drilling mud. Further research is required to evaluate on-site performance of the CSMED at Eromanga and validate the simulation in this study.

\section{Acknowledgement}

This study is financially supported by the Australian Government via the Innovation Connection Scheme (Grant number: ICG001550). 
Tables

Table 1. Produced water quality at the Kenmore oil field and water quality guideline for different usage

\begin{tabular}{|c|c|c|c|c|c|}
\hline $\begin{array}{l}\text { Water } \\
\text { parameters }\end{array}$ & $\begin{array}{l}\text { Produced water } \\
(\text { mean } \pm \text { std })\end{array}$ & Livestock & Irrigation & $\begin{array}{l}\text { Municipal } \\
\text { use * }\end{array}$ & Potable \\
\hline $\mathrm{pH}$ & $8.7 \pm 0.35$ & $5.5-8.5$ & $6-8.5$ & $6-8.5$ & $6.5-8.5$ \\
\hline $\begin{array}{l}\text { Electrical } \\
\text { conductivity } \\
(\mu \mathrm{S} / \mathrm{cm})\end{array}$ & $2745.0 \pm 3835.4$ & $<950$ & $<650{ }^{A}$ & $<650{ }^{A}$ & $<400$ \\
\hline TDS (mg/L) & $1817.4 \pm 2717.6$ & $<4000^{\mathrm{B}}$ & NA & NA & $<600$ \\
\hline $\begin{array}{l}\text { Bicarbonate } \\
\text { alkalinity as } \\
\mathrm{CaCO}_{3}(\mathrm{mg} / \mathrm{L})\end{array}$ & $582 \pm 11$ & $<\mathbf{5 0 0}$ & $90-120$ & $90-120$ & NA \\
\hline Sodium $(\mathrm{mg} / \mathrm{L})$ & $346 \pm 43.8$ & NA & $<115^{A}$ & $<115^{A}$ & $180^{\mathrm{C}}$ \\
\hline Chloride $(\mathrm{mg} / \mathrm{L})$ & $329 \pm 454$ & $<400$ & $<175^{A}$ & $<175^{A}$ & $<250^{\mathrm{C}}$ \\
\hline $\begin{array}{l}\text { Total hardness as } \\
\mathrm{CaCO}_{3}(\mathrm{mg} / \mathrm{L})\end{array}$ & 119 & & $<60^{\mathrm{F}}$ & $<60^{\mathrm{F}}$ & $<200^{\mathrm{C}}$ \\
\hline SAR & $45.1 \pm 33.2$ & NA & $8-18^{A}$ & $8-18^{A}$ & $\mathrm{NA}$ \\
\hline Calcium (mg/L) & $19.5 \pm 4.9$ & 1000 & 1000 & 1000 & NA \\
\hline $\begin{array}{l}\text { Magnesium } \\
(\mathrm{mg} / \mathrm{L})\end{array}$ & 15 & NA & NA & NA & $\mathrm{NA}$ \\
\hline Fluoride (mg/L) & $6.3 \pm 2.0$ & 1 & $1^{\mathrm{D}}-2^{\mathrm{E}}$ & $1^{\mathrm{D}}-2^{\mathrm{E}}$ & 1.5 \\
\hline
\end{tabular}

Table 2. Validation test conditions

\begin{tabular}{|c|c|c|}
\hline Parameter & Test 1 & Test 2 \\
\hline Solar irradiance $\left(\mathrm{W} / \mathrm{m}^{2}\right)$ & $182-589$ & $174-268$ \\
\hline Running time (min) & 26 & 58 \\
\hline Temperature $\left({ }^{\circ} \mathrm{C}\right)$ & 31 & 25.6 \\
\hline Humidity (\%) & 66 & 44 \\
\hline Pressure (mbar) & 1021 & 1025 \\
\hline Winds $(\mathrm{km} / \mathrm{h})$ & $9.6-19.3$ & $22.5-24.1$ \\
\hline Feed water makeup & $\begin{array}{l}\text { City water } 1184 \mathrm{~L} \text { at } 160 \\
\mathrm{mg} / \mathrm{L} \text { TDS mixed with } 36 \mathrm{~kg} \\
\text { pool salt }\end{array}$ & $\begin{array}{l}\text { City water at } 348 \\
\mathrm{mg} / \mathrm{L} \text { TDS mixed with } \\
\text { sand at } 50 \% \text { by weight }\end{array}$ \\
\hline Waste brine & 9990 (mg/L) TDS & $\begin{array}{l}12-14 \% \text { moisture } \\
\text { content }(\mathrm{w} / \mathrm{w})\end{array}$ \\
\hline
\end{tabular}

Table 3. Blending ratio (bypass: treated water) to make up product water for livestock watering at $1 \mathrm{mg} / \mathrm{L}$ of fluoride

\begin{tabular}{lrrr}
\hline \multicolumn{1}{c}{ Water parameters } & $\begin{array}{c}\text { Livestock } \\
\text { watering }\end{array}$ & $\begin{array}{c}\text { Blending ratio } \\
\text { \% (v/v) }\end{array}$ & $\begin{array}{c}\text { Product } \\
\text { water }\end{array}$ \\
\hline $\mathrm{pH}$ & $5.5-8.5$ & & $\mathrm{NA}$ \\
\hline Electrical conductivity $(\mu \mathrm{S} / \mathrm{cm})$ & $<950$ & 19 & 432 \\
\hline Bicarbonate alkalinity as $\mathrm{CaCO}_{3}(\mathrm{mg} / \mathrm{L})$ & $<500$ & 19 & 91.6 \\
\hline Fluoride $(\mathrm{mg} / \mathrm{L})$ & 1 & 19 & 1 \\
\hline
\end{tabular}


Table 4. Blending ratio (by-pass: treated water) to make up product water for irrigation at $1 \mathrm{mg} / \mathrm{L}$ of fluoride

\begin{tabular}{lrrr}
\hline \multicolumn{1}{c}{ Water parameters } & Irrigation & $\begin{array}{c}\text { Blending ratio } \\
\text { \% }(\mathbf{v} / \mathbf{v})\end{array}$ & $\begin{array}{c}\text { Product } \\
\text { water }\end{array}$ \\
\hline $\mathrm{pH}$ & $6-8.5$ & 19 & na \\
\hline Electrical conductivity $(\mu \mathrm{S} / \mathrm{cm})$ & $<650$ & 19 & 432.1 \\
\hline Bicarbonate alkalinity as $\mathrm{CaCO}(\mathrm{mg} / \mathrm{L})$ & $90-120$ & 19 & 91.6 \\
\hline Total hardness as $\mathrm{CaCO}_{3}(\mathrm{mg} / \mathrm{L})$ & $<60$ & 19 & 18.7 \\
\hline Chloride $(\mathrm{mg} / \mathrm{L})$ & $<175$ & 19 & 51.8 \\
\hline Fluoride $(\mathrm{mg} / \mathrm{L})$ & $1-2$ & 19 & 1 \\
\hline Sodium $(\mathrm{mg} / \mathrm{L})$ & $<115$ & 19 & 54.5 \\
\hline Calcium $(\mathrm{mg} / \mathrm{L})$ & 1000 & & 3.10 \\
\hline Magnesium $(\mathrm{mg} / \mathrm{L})$ & $\mathrm{Na}$ & & 2.38 \\
\hline SAR & $8-18$ & 19 & 8.04 \\
\hline
\end{tabular}

Table 5. Blending ratio (by-pass: treated water) to make up product water for drinking water at $1.5 \mathrm{mg} / \mathrm{L}$ of fluoride and $400 \mu \mathrm{S} / \mathrm{cm}$ of electrical conductivity

\begin{tabular}{lrrrrr}
\hline Water parameters & Potable use & $\begin{array}{l}\text { Blending } \\
\text { ratio \% } \\
(\mathbf{v} / \mathbf{v})\end{array}$ & $\begin{array}{l}\text { Product } \\
\text { water }\end{array}$ & $\begin{array}{l}\text { Blending } \\
\text { ratio \% } \\
\text { (v/v) }\end{array}$ & $\begin{array}{l}\text { Product } \\
\text { water }\end{array}$ \\
\hline $\mathrm{pH}$ & $6.5-8.5$ & 31 & $\mathrm{Na}$ & 17 & $\mathrm{Na}$ \\
\hline $\begin{array}{l}\text { Electrical conductivity } \\
(\mu \mathrm{S} / \mathrm{cm})\end{array}$ & $<400$ & 31 & $\mathbf{6 5 0}$ & 17 & 400 \\
\hline $\mathrm{TDS}(\mathrm{mg} / \mathrm{L})$ & & & & & \\
\hline Sodium $(\mathrm{mg} / \mathrm{L})$ & 180 & 31 & 430 & 17 & 264 \\
\hline Chloride $(\mathrm{mg} / \mathrm{L})$ & $<250$ & 31 & 82 & 17 & 50.4 \\
\hline Fluoride $(\mathrm{mg} / \mathrm{L})$ & 1.5 & 31 & 78 & 17 & 48 \\
\hline
\end{tabular}




\section{Figures}

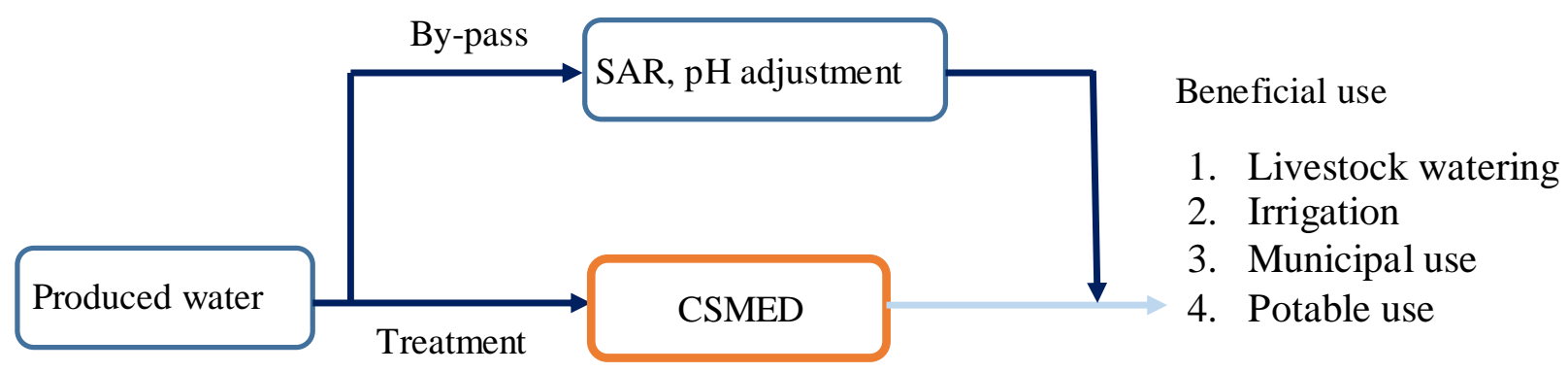

Fig. 1. A diagram of the treatment scheme. 
(a)

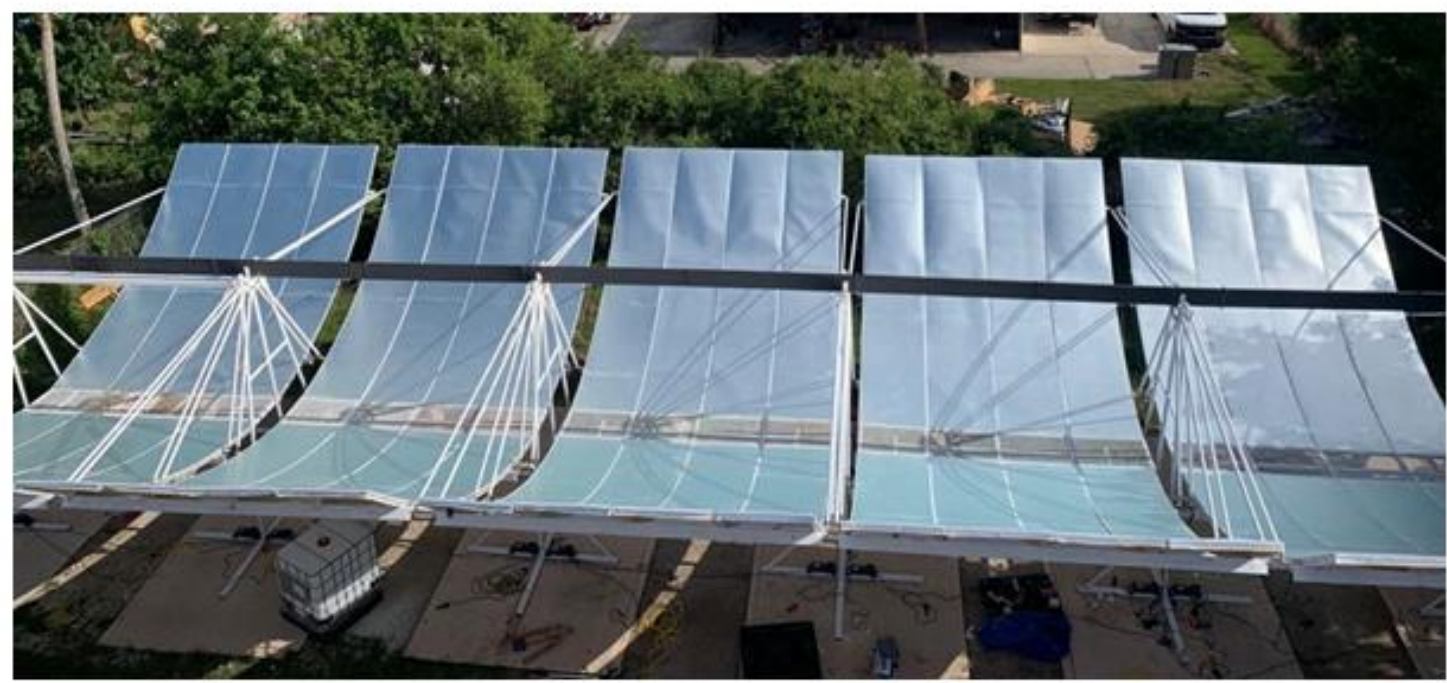

(b)

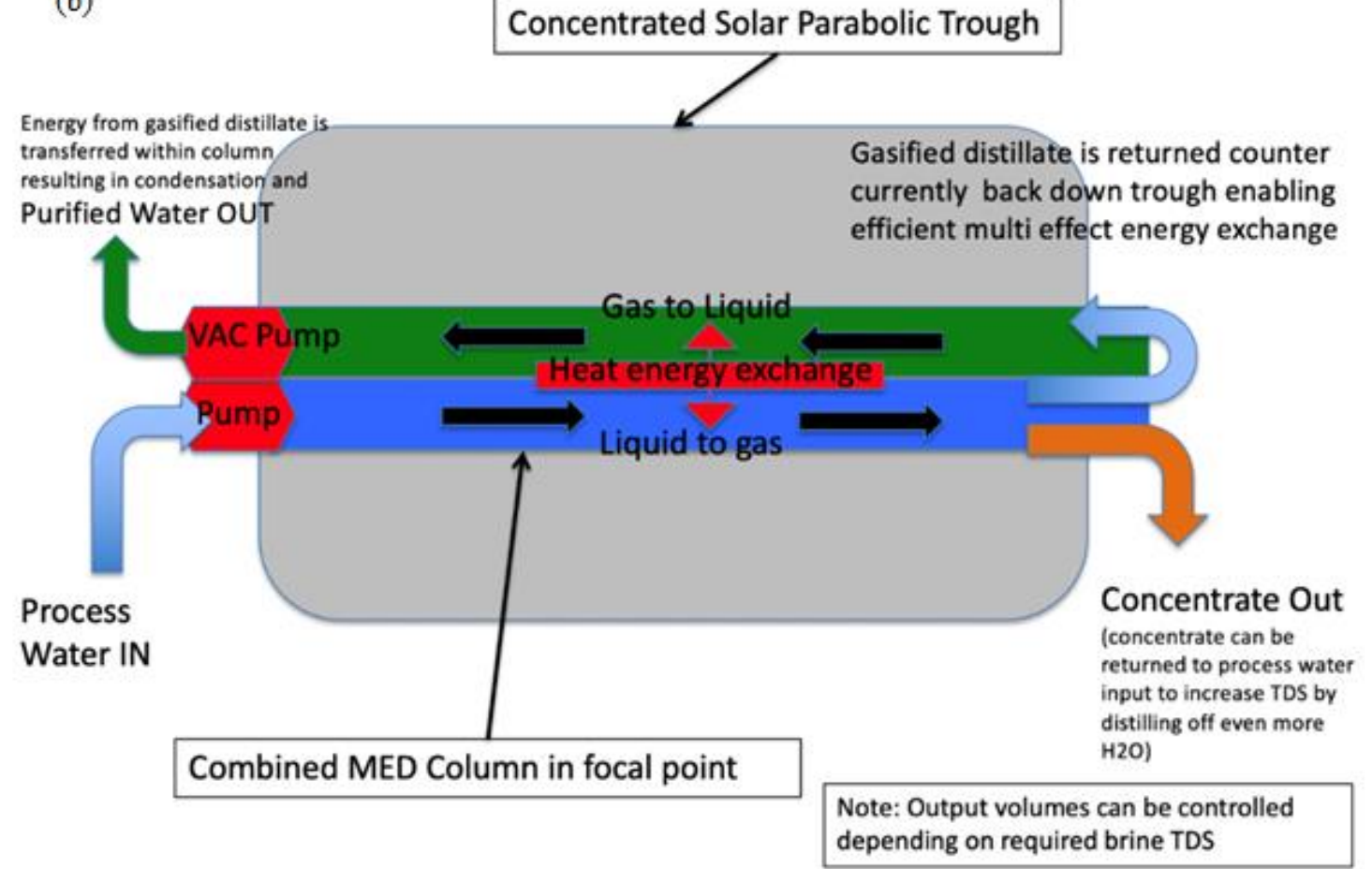

Fig. 2. A photograph of the CMSED unit (a) and a schematic diagram explains the process in the multi effect distiller (b)

\section{Conflicts of interest}

All authors confirm there are no conflicts of interest.

\section{Reference}

ANZECC. 2000. Australian and New Zealand Guidelines for Fresh and Marine Water Quality. Commonwealth of Australia, Canberra. 
Blair, D., Alexander, D.T., Couperthwaite, S.J., Darestani, M., Millar, G.J. 2017. Enhanced water recovery in the coal seam gas industry using a dual reverse osmosis system. Environ. Sci. Water Res. Technol., 3(2), 278-292.

https://solargis.com/maps-and-gis-data/download/australia.

Millar, G.J., Couperthwaite, S.J., Moodliar, C.D. 2016. Strategies for the management and treatment of coal seam gas associated water. Renew. Sustain. Energy Rev, 57, 669-691.

Nghiem, L.D., Ren, T., Aziz, N., Porter, I., Regmi, G. 2011. Treatment of coal seam gas produced water for beneficial use in Australia: A review of best practices. Desalin. Water Treat., 32(13), 316-323.

NHMRC, NRMMC. 2019. Australian Drinking Water Guidelines Paper 6 National Water Quality Management Strategy. National Health and Medical Research Council, National Resource Management Ministerial Council, Commonwealth of Australia, Canberra.

Skinner, J.E., Altmann, M.J., Wadham, T.H. 2006. More wells, more oil: A case study of reserves growth in the Kenmore field The APPEA Journal, 46(1), 35-46.

Tao, P., Ni, G., Song, C., Shang, W., Wu, J., Zhu, J., Chen, G., Deng, T. 2018. Solar-driven interfacial evaporation. Nature Energy, 3(12), 1031-1041.

Watts, K.J. 1987. The Hutton Sandstone-Birkhead formation transition, ATP 269P(1), Eromanga Basin The APPEA Journal, 27(1), 215-229.

Yao, R., Jiang, G., Li, W., Deng, T., Zhang, H. 2014. Effect of water-based drilling fluid components on filter cake structure. Powder Technology, 262, 51-61.

\section{Authors}

Ralph Gunness

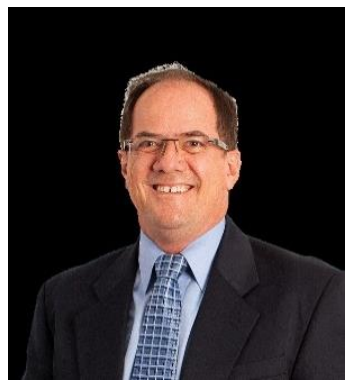

Ralph Gunness is the Environmental and Compliance Manager for the Bridgeport Energy group of companies and his role is to implement the Environmental and Health and Safety requirements for their operations. This role includes management of the treatment of produced water and its beneficial uses within the community. Ralph has degrees in Business Management, Environmental Studies, Training, \& Agricultural Science. Ralph has published or presented 30 papers on CSG water, the uses of CSG water environment and associated topics. He pioneered the application of Reverse Osmosis CSG water treatment and the beneficial use of CSG water for agribusiness. In 2007, Ralph \& his team received several national and international awards for innovative environmental management associated with water processing, energy conservation, and beneficial use.

Ronald is Environmental Projects Lead at JWA Oilfield Supplies. He holds an honours degree in business (finance) and a Master of environment and sustainability bringing knowledge and experience from his time in the resources, telecommunications, sustainability, and government sectors. He has provided advice to clients to maximise financial and environmental outcomes while minimising project risk for large capital projects. Previously, he was the Queensland state manager 
for a consultancy building strategic partnerships, managing sustainability projects, and leading business development. Currently, Ronald is playing a key role in sourcing funding and supporting commercialisation efforts of JWA's novel Concentrated Solar Multi-Effects Distillation technology.

\section{Hensley Wee}

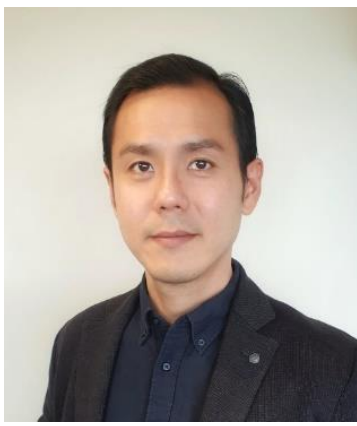

Luong N. Nguyen

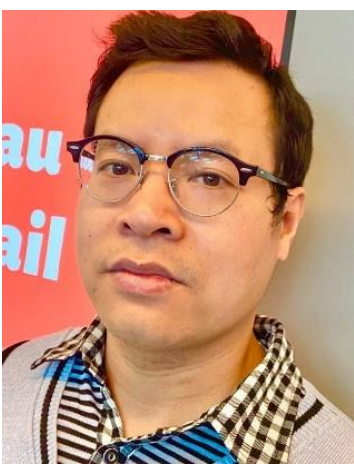

Hensley Wee is the Director of Business Development at JWA Oilfield Supplies leading product sales strategy, implementation, and execution. Experienced in closing direct sales and developing strategic partners within the resource industry. Hensley has a proven track record in commercialising novel technology with beneficial environmental impacts into major energy projects in India, Papua New Guinea, Kazakhstan, and Australia over his 20-year career.

Luong Nguyen is a research fellow at Center for Technology in Water and Wastewater. He has five years of experience in water industry and R\&D environments with major sector clients (Sydney Water, GHD). He was trained at University of Wollongong for Master (2012) and $\mathrm{PhD}$ degree (2015) in environmental engineering. His career aims to produce clean and affordable water for beneficial reuses from non-conventional water sources such as saline water, brackish water, and wastewater. He has led highly successful projects such as membrane filtration for potable water production, membrane distillation for brine treatments.

\section{Long D. Nghiem}

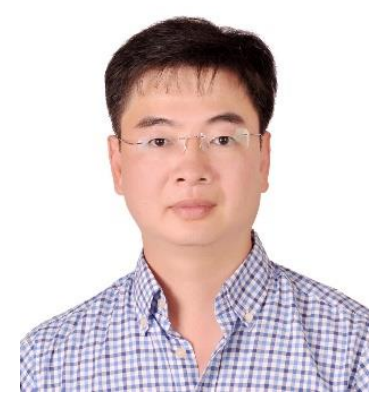

Long Nghiem is a Professor and the Director of the Centre for Technology in Water and Wastewater. His current research centres around the Water Energy - Food nexus with a focus on energy efficient water treatment and resource recovery. He has led several large-scale research projects to develop and implement the extraction of clean water from alternative sources including coal seam gas produced water for beneficial uses. Long has worked at Colorado School of Mines for 6 months as a visiting professor (in 2009) and the Technical University of Munich for 3 months as an August-Wilhelm Scheer Visiting Professor (in 2016). 


\section{Appendix:}

List of equations for calculation of bypass ration in the Excel based model

$$
\begin{gathered}
C_{f} \times V_{f}=C_{b} \times V_{b}+C_{t} \times V_{t} \\
V_{f}=V_{b}+V_{t} \\
C_{f} \times\left(V_{b}+V_{t}\right)=C_{b} \times V_{b}+C_{t} \times V_{t} \\
V_{b}=\frac{C_{t} \times V_{t}-C_{f} \times V_{t}}{C_{f}-C_{b}}
\end{gathered}
$$

Where, $\mathrm{C}$ is the concentration of a water parameter with $\mathrm{f}=$ final, $\mathrm{b}=$ bypass, and $\mathrm{t}=$ treated. For example, $\mathrm{C}_{\mathrm{f}}$ is the concentration of a water parameter in the product water. $\mathrm{V}$ is the volume of water with $\mathrm{f}=$ final, $\mathrm{b}=$ bypass, and $\mathrm{t}=$ treated. 